\title{
Resisting the Present: Biopower in the Face of the Event (Some Notes on Monstrous Lives)
}

\author{
Thomas Clément MERCIER \\ (ANID FONDECYT, Universidad Adolfo Ibañez)
}

This is the author's manuscript of an article published in 2019 in CR: The New Centennial Review. The issue (19.3) collected essays written around the theme 'After Biodeconstruction', after the book of the same name by Francesco Vitale, Biodeconstruction: Facques Derrida and the Life Sciences, translated by Mauro Senatore (New York: SUNY Press, 2018).

\section{To cite this article:}

- Thomas Clément Mercier, 'Resisting the Present: Biopower in the Face of the Event (Some Notes on Monstrous Lives)', CR: The New Centennial Review, Vol. 19, No. 3, 2019, pp. 99-128.

- Link: https://www.jstor.org/stable/10.14321/crnewcentrevi.19.3.0099

\begin{abstract}
In its hegemonic definition, biopolitical governmentality is characterised by a seemingly infinite capacity of expansion, susceptible to colonise the landscape and timescape of the living present in the name of capitalistic productivity. The main trait of biopower is its normative, legal and political plasticity, allowing it to reappropriate critiques and resistances by appealing to bioethical efficacy and biological accuracy. Under these circumstances, how can we invent rebellious forms-of-life and alternative temporalities escaping biopolitical normativity?

In this essay, I interrogate the theoretical presuppositions of biopolitical rationality. I provide a deconstruction of the conceptual and temporal structures upholding the notion of biopolitics, in view of laying the ground for new forms of resistance. The articulation between life and power has a long philosophical history, which has been largely ignored by social theorists and political thinkers using biopolitics as an interpretative model. I re-inscribe this model within the tradition of critical materialism, by articulating Foucault's 'critical ontology' to recent philosophical works on biological plasticity (Malabou). In these discourses, the logic of biopower depends on a representation of life - 'the living' - as living present. Biopower finds itself anchored in the authority of the present, that is to say, of being-as-presence (ontology); it sustains presentist definitions of life and materiality, be it under the form of a 'plastic' ontology. By drawing on Derrida's notions of 'spectrality' and 'life-death' and Francesco Vitale's work on 'biodeconstruction', I deconstruct these discourses on life and materiality and attempt to dissociate them from their ontological grounding, in order to suggest new paths of resistance to biopower. In particular, I follow the tracks of "the monster" in the work of Foucault, Derrida and Malabou. Foucault tells us that the monster is a singular figure, parasitic and subversive, beckoning a life beyond life, at once organic and non-organic, located at the limit between the normal and the exceptional, and exceeding the scope of biopolitical normativity in both theoretical and practical terms. It exists at the intersection of what Foucault names "the symbolics of blood" and "the analytics of sex". As such, it materialises a self-transformative dimension of the living which remains, I argue, inadequate to Malabou's representation of plasticity. The monstrous is a self-deconstructive motif calling for another biopolitical rationality, before or beyond ontological reductions or reconstructions.
\end{abstract}




\title{
Resisting the Present: Biopower in the Face of the Event (Some Notes on Monstrous Lives)
}

\author{
Thomas Clément MERCIER \\ (ANID FONDECYT, Universidad Adolfo Ibañez)
}

What imparts itself in the promise must therefore go beyond all forms of transcendental subjectivity and their politico-economic institutions, it must go beyond capital and the labor which it determines, and from this exceedence it must transform all its figures in advance, transform them by promising them and shifting them into the "trans" of every form. From its very inception, it must be beyond everything posited in any way, a monster at the limit of appearance, of visibility and representability. It must be, however so gently, an ex-positing.

- W. Hamacher (1999, 193)

Writing, like all artificial languages one would wish to fix and remove from the living history of the natural language, participates in the monstrosity.

— J. Derrida $(1997,38)$

the old word vie [le vieux nom de vie] perhaps remains the enigma of the political around which we endlessly turn.

— J. Derrida $(2005 b, 4)$

I hold Francesco Vitale's Biodeconstruction to be a major book on, and of, resistance.

Vitale not only thinks of a certain resistance of life - and, as we shall see, of life resisting itself, thus resisting the selfhood of a self, any self - but also allows for rethinking what "resistance" means. Biodeconstruction compels us to reconsider that old name, "resistance"; it brings out the possibility of resisting resistance in order to think of resistance as what resists itself, in its "own" name, and perhaps beyond any name. As if the name "resistance" were itself the site of an immemorial resistance, a dam erected against another force of resistance, perhaps more potent but also less forgiving: 
a resistance of life against the "itself" of life, before and beyond the being of life "itself." A resistance that resists naming. Resistance in and against naming. This suggests a resistance prior to ontology and, in particular, prior to ontological reductions of life. Résistance sans l'être: resistance without being (it). This is not nothing. ${ }^{1}$

Through readings of François Jacob's The Logic of Life- always carefully articulated with philosophers, notably Aristotle and Hegel - Vitale shows, in the wake of Derrida's 1975-1976 seminar "La vie la mort," that resistance has traditionally been conceived of as a function of life, of life understood as "self-reproduction" (Vitale 2018, 80-90). This definition of the essence of the living as self-reproduction betrays "the sedimentation of the oldest metaphysical matrix able to determine philosophies and the life sciences over the centuries" (81). Life, the name "life," thus designates "the capacity of reproducing itself" (Derrida, quoted in Vitale 2018, 82). It supposes the teleological essence of life as dynamis and energeia. But if what we call "life" is defined as reproducibility, this definition of the essence of life in fact espouses the definition of essentiality itself, of the power of the essence (the concept or idea) to be repeated and reproduced in and through all its alterations or transformations, to reproduce itself without interruption and without remainder: "the dynamics and energy of being, what gives the potentiality and act of being" and "secures from the inside its own production, namely, its re-production" (Derrida, in Vitale 2018, 82). The circle of life is thus the life of the circle: the logic of the living, or the life of onto-logic. Life is the

\footnotetext{
${ }^{1}$ Here I will not speak about Derrida's restance, but the following quotation might be an important index for what follows: "The rest 'is' not, because it is not what remains, in the stance, substance, or stability. What I call restance no longer comes to modify Being or the presence of Being. It indicates a repetition, an iterability rather, which no longer takes shape only on the basis of Being or beingness. Whence the question of cinders, of the cinder without spirit, without phoenix, without rebirth, and without destiny: perhaps the death of the hedgehog, its exposure to disappearance without remainder [sans reste].... The rest can always not remain [rester] in the classic sense of the term, in the sense of substance. This is the condition for there being any remainder. On the condition that it cannot remain, that it can happen to it not to remain" $(1995,323)$.
} 
corpus of a self-sustaining body proper, internally produced and re-produced in its own name. It is also the phantasm of capital. ${ }^{2}$

In this perspective, the power of life conflates with its own logic - logic - that of selfreproduction. It is "the movement of the phoenix" (Derrida, in Vitale 2018, 38), ipseity as power of the autos: reproduction of the self-same, life itself, purified and immortal despite accidental differences or contingent determinations, natural deaths or local resistances. In this particular sense, life is essentially power, life-power. Life is power of the essence. Can one break the circle and resist "the movement of the phoenix"?3 And would it make sense to call this a "resistance" - perhaps a "political," or "biopolitical" resistance?

In Biodeconstruction, Vitale invokes the necessity of a "debate between biopolitics and (bio)deconstruction" (234). He indicates in several places the coordinates of the future debate, usually in relation to Roberto Esposito's work on biopolitical immunity. Here I will do something a little different, though hopefully faithful to some of the theoretical premises outlined so brilliantly by Vitale. I would like to interrogate what I am tempted to call the conditions of possibility of biopolitical rationality. My goal is to examine the ontological presuppositions of the discourse of biopolitics or biopower. Michel Foucault used the terms "biopolitics" and "biopower" interchangeably, but

\footnotetext{
${ }^{2}$ In 1974-1975, a year before "La vie la mort," Derrida's seminar dealt with Marxist discourses and political economy. In that context too, the concept of self-reproduction was one of the main targets of Derrida's deconstructive efforts. I provide a reading of that unpublished seminar in Mercier 2019.

${ }^{3}$ In "The phoenix, the spider, and the salamander" (2011a, 67-89), Malabou opposes the salamander's fragile power of plastic regeneration to Hegel's all-mighty phoenix. However, as will progressively appear, Malabou's salamander has more in common with Hegel's dialectical phoenix - from the standpoint of the plasticity of life "itself" - than Malabou is ready to acknowledge in that text. Compare, for instance, with Derrida's hedgehog. Let me note two things in passing: first, the salamander's plastic regeneration is explicitly said to be non-monstrous (82); second, plasticity (be it life's, the brain's, or ontological plasticity) is systematically described by Malabou in terms of power, possibilities, potential, capacity, or ability pertaining to a self (80-89). For instance, elsewhere: "Existence reveals itself as plasticity, as the very material of presence, as marble is the material of sculpture. It is capable of receiving any kind of form, but it also has the power to give form to itself' (2010, 81). Plasticity is always depicted under the traits of dynamis - one that supposes self-property as self-potential. It is the self-flexion of life, self-power as auto-affection (on this, see Vitale 2018, 77-84).
} 
here I prefer to speak about "biopower" because it maintains an explicit reference to the mastery of power, pouvoir, and therefore to the lexicon of possibility, potentiality, force and dynamis. ${ }^{4}$ As we shall see, although biopower is thought in opposition to sovereign power, it shares with it important features, of which the continuous reference to power (and power-knowledge) is the index. In unpacking methodological problems consubstantial with the biopower analytics, I hope to emphasize aspects that remain, I believe, insufficiently theorized or thematized in the literature on biopolitics. Specifically, I will point to a certain temporal structure of biopolitical rationality, namely, its continuous dependence on the authority of the present. Through readings of texts by Foucault, Malabou, and Derrida, I will argue that the logic of biopower performs itself through the exclusion of an exorbitant monstrosity, a monstrous life beyond life, beyond presence, and beyond being. "Life" makes itself possible in excluding the monstrous impossible and its irreproducible singularity.

The lexicon of biopolitics has become pervasive. It has been appropriated by a multitude of discourses, academic or not, and by many disciplines or sub-disciplines in the Humanities and beyond. "Biopolitics": we seem to know what that thing is, what that name designates. But let me say this upfront: "biopower" and "biopolitics" do not stand for anything simple at all. Foucault first used those terms in March 1976 in the last of his 1975-1976 lectures at the Collège de France, "Society Must Be Defended" (2003b, 239-264). I note in passing that the scene is exactly contemporaneous with Derrida's seminar "La vie la mort." Foucault then put those terms in print for the first time in October of the same year, 1976, in the first volume of History of Sexuality. He initially conceived of biopower as a technology of government that appeared at the end of the eighteenth century and focused on the control of populations and the

\footnotetext{
${ }^{4}$ I explore these notions in Mercier (2018).
} 
normalization of behaviors. ${ }^{5}$ It is "a power whose highest function [is] perhaps no longer to kill, but to invest life through and through" (1978, 139). Biopower involves "control over relations between the human race, or human beings insofar as they are a species, insofar as they are living beings, and their environment, the milieu in which they live" (2003b, 245). Foucault defines the objects of biopower as such: "biopolitics will derive its knowledge from, and define its power's field of intervention in terms of, the birth rate, the mortality rate, various biological disabilities, and the effects of the environment" (245). But the key feature of biopolitical rationality is that Foucault defines it in opposition to sovereignty:

Beneath that great absolute power, beneath the dramatic and somber absolute power that was the power of sovereignty, and which consisted in the power to take life, we now have the emergence, with this technology of biopower, of this technology of power over "the" population as such, over men insofar as they are living beings. It is continuous, scientific, and it is the power to make live. Sovereignty took life and let live. And now we have the emergence of a power that I would call the power of regularization, and it, in contrast, consists in making live and letting die. (2003b, 247)

As is well known, biopolitics implies what Foucault calls "the norm." The definition of a normative life - a "good" or "better" life, perhaps a more "productive" one - is described as consubstantial with biopower; by the same token, the normative "produces" abnormalities, but not outside of itself. Biopower does not exclude; it aims to correct and regulate. In the first volume of History of Sexuality, Foucault describes biopower's recourse to normativity, here again in opposition to the logic of Law and sovereign power:

Another consequence of this development of bio-power was the growing importance assumed by the action of the norm, at the expense of the juridical system of the law. Law cannot help but be armed, and its arm, par excellence, is death; to those who transgress it, it replies, at least as a last resort, with that absolute menace. The law

\footnotetext{
${ }^{5}$ In the following years, Foucault progressively left aside the biopolitical lexicon and focused on neoliberal governmentality and the government of the self and others.
} 
always refers to the sword. But a power whose task is to take charge of life needs continuous regulatory and corrective mechanisms. It is no longer a matter of bringing death into play in the field of sovereignty, but of distributing the living in the domain of value and utility. $(1978,144)$

Foucault thus opposes the seeming rigidity of sovereign power and law to the apparent flexibility of biopower and its object, life "itself." He emphasizes the changing continuity of biopolitical norms, their corrective and self-corrective character - perhaps what Catherine Malabou would call a plastic understanding of the norm. As Foucault says: "The phenomena addressed by biopolitics are, essentially, aleatory events that occur within a population that exists over a period of time" (2003b, 246). Biopolitics must do with the passing of time and thus requires both continuity and adaptability. There is a flexibility and evolutivity of normative functions, depending on a certain calculability of risks and accidents. The norm is a futurological exercise (2003b, 246); it supposes both the predictability and unpredictability of the event, which has to do with a certain anachrony of the present: one must predict and calculate in order to voir venir, "to see (what is) coming" (Derrida, 2005a) - be it to resist or to secure the future, in the present. This futurological function also relates to the notion that biopower is intrinsically transformative. Biopower designates

what brought life and its mechanisms into the realm of explicit calculations and made knowledge-power an agent of transformation of human life. It is not that life has been totally integrated into techniques that govern and administer it; it constantly escapes them. (Foucault 1978, 143).

So, even though Foucault strives to distinguish the economy of biopower from the structures of sovereignty and law, and however relevant this distinction might be in theoretical or historiographical terms ${ }^{6}$ biopower and sovereignty still share the need

\footnotetext{
${ }^{6}$ For this type of analysis in relation to Foucault and Agamben, see Derrida 2009.
} 
to secure the present (and the future) from the event. It is their ontological milieu, so to say. I am thus tempted to read Foucault's description of the biopolitical logic together with Derrida's deconstructive reading of performativity in Rogues - what Derrida calls here, as an implicit nod to Foucault's analytics, "power-knowledge" and "knowledge-power." As Derrida explains, the (bio)power of the norm must be performative, which supposes the neutralization of the event:

A calculable event, one that falls, like a case, like the object of some knowledge, under the generality of a law, norm, determinative judgment, or technoscience, and thus of a power-knowledge and a knowledge-power, is not, at least in this measure, an event. . . .

A performative produces an event only by securing for itself, in the first-person singular or plural, in the present, and with the guarantee offered by conventions or legitimated fictions, the power that an ipseity gives itself to produce the event of which it speaks - the event that it neutralizes forthwith insofar as it appropriates for itself a calculable mastery over it. (2005b, 148-152)

Biopolitics, like sovereignty, though differently, thus depends on the priority given to the self-sameness of ipseity, that is, the presupposition of the authority of selfpresence, of the present "itself." This is what Derrida named, in Rogues, "ipsocentrism" or "ipsocracy" (17). In its normalizing power, biopolitical rationality strives to do away with the structural anachrony of the present: we know that the future is coming, and we arm ourselves against it, in the name of a predictable and manageable future. In this way, both sovereign power and biopower are ontological gestures. But here, a (bio)deconstructive reading allows for a supplementary fold - at least a triple folding - that is structurally forbidden by Foucault's biopower analytics, inscribed as it is in "an ontology of the present" (2007, 95), a "historical," "critical ontology of ourselves" (114-115). Biodeconstruction raises the following question: Is biopower such as described by Foucault simply an object of critical inquiry (as seems to be Foucault's conception), or is biopolitical rationality already speaking through Foucault's analyses - Foucault who was, let it be known, a "living being," and himself 
a subject and object of biopower? ${ }^{7}$ Can we absolutely stabilize this play of differantial supplementarity, involving at least four analytical layers: not only 1) "life itself"; but also 2) what we call "bio-logy," and more generally all discourses that supposedly take "life" as their object (that is, a virtually unlimited field); but also 3) biopower "strictly speaking," that is, the biopolitical practices that supposedly instrumentalize those discourses in order to "invest" life politically and strategically; and also 4) the analytics of the discourse on biopower - the discourse of the biopolitologist - an observer or theorist who is himself or herself a human, living being, and therefore a subject and object of all aforementioned discourses and practices, and, in fine, an expression of "life itself"? Now, the apparent circularity I have just described - starting with "life itself" and returning to "life itself" - cannot and should not be understood as a circle, precisely. The circle of life never gives itself as such. Each of these four layers gives itself only as text, to be read and interpreted, translated, informed and transformed. They mark or remark each other, performatively "produce" each other through forceful incisions and selections, violent effects of translation and substitution, unstable alliances and transformative resistances. The four layers of the fold must read each other, cut, write, describe, prescribe, define each other; they aim to normalize each other for the sake of sustenance, reproduction, perhaps intelligibility or clarity, in the effort of stabilizing the present. But in doing so they open themselves to heterogeneity, alteration, betrayal and contamination. Where does the limit pass between each of the four layers folded into this "auto-hetero-bio-thanatographical" scene?

Now is as good as any time to explain my title. When I chose "Resisting the Present," my intention was to translate something that resists translation. In French, my title

\footnotetext{
${ }^{7}$ On what follows, see Vitale 2018, 29-30 and 105-113.
} 
would have been "Résister au présent," which might be understood in at least two different ways - two meanings which I believe are at once indissociable and irreducibly heterogeneous. First, résister au présent can signify "resisting the present," in the sense that the present must be resisted, because there must be something else than the present, something beyond the presence of the present which escapes present norms or conventions. One must resist the present categories that inform theory and practice so that there can be a future. In this sense, there must be an essential anachrony of the present, an anachrony in both diachronic and synchronic terms: "Time is out of joint" (Derrida 1994). It is, in fact, an irreducible structure of temporality: the present is always-already resisted; the present resists itself. But, in a second sense, résister au présent can also signify "to resist in the present." One may resist only in the present. What I mean by this is that even though resistance always targets the present, the present state of affairs, it can only depart from the present: resistance finds its force, its resources, its critical tools or deconstructive levers in the present. It resists from the present. Deconstruction targets present structures, that is, structures that have been constituted as such, as present, through forceful effects of presencing or ontologization. Resistance happens against the present, in all senses of the term "against": it is a form of opposition that requires contact, and therefore contamination. There is no pure resistance, no appeal to a "beyond" that can fully avoid this sort of contaminating negotiation: the beyond is within. This is, at bottom, what reading means. While choosing this title my intention was to emphasize that these two significations of résister au présent both require and resist each other, at once or in turn, in heterogeneity - quite simply because this double dimension is required by the present: it is the very structure of what one calls "the present."

What I am doing here is basically rehashing and justifying my title, a title chosen a long time ago. This title is now printed. It exists in print, and it exists as such in spite of the translation issues I have just described. Here I am, repeating this title and running after all its competing and concurring potentialities or possibilities. I try to 
actualize these incompatible potentialities one more time, in the desperate hope that they become alive again, present, presently alive - once again, for the reader. This ridiculous comedy, this out-of-breath performance, one could say that it testifies to the plasticity of my title, that is to say the coexistence, in its being, in its very presence, of competing forms, possibilities, or virtualities allowing for its potential transformability. Now, on the subject of plasticity, Catherine Malabou writes:

If we keep the definition of the symbolic as an empty or vacant space, this empty space is currently becoming what I call the plastic space or the locus of plasticity, something that allows play within the structure, that loosens the frame's rigidity - the frame being biological determinism. The symbolic here appears as that which allows the interplay of determinisms and freedom within the frame or the structure. This symbolic biological dimension is the transformative tendency internal to materiality, the selftransformative tendency of life. It is life transforming itself without separating itself from itself. I would like to conceive of life as possessing its own modes of self-transformation, self-organization, and self-directedness. $(2015,44-45)$

It is true that the double structure I have just described - "resisting (in) the present"might at first glance seem close to some of Malabou's reflections on the paradoxes of resistance conceived of as an internal resistance of life against itself (2011b). In recent years, Malabou has focused her analysis of the concept of resistance around the notion of biopolitics (2015; 2016). For instance, in "Will Sovereignty Ever Be Deconstructed?" Malabou criticizes Foucault, Agamben, and Derrida for misunderstanding or neglecting the plastic dimension of biological life. She claims that the three thinkers postulate a separation between what she calls "symbolic freedom" and "biological determinism." Malabou contests this separation because life "itself" contains, in its intrinsic material resources, in its radical immanence, all capacities of resistance against biopolitical normativity, that is to say: against itself. The biological, she claims, has always been plastic, that is, self-transformative, metamorphic and evolutional - this is an essential dimension of her reinterpretation of Hegelian and Heideggerian thought, for instance, through emphasis on plasticity. 
Plasticity suggests the absolute immanence of life. In its last consequences, the logic of plasticity is an ontological postulation in materialistic terms. Life contains in itself all the resources of its own becoming, that is, the plastic force of a future in and for life. As Malabou repeatedly affirmed in recent years: "There is but one life, one life only" (2016, 438; 2019, 144).

I will return to Malabou's critique of biopolitics in conclusion. First, I wish to emphasize another sense of "anachrony," one that seems to exceed the temporal structures on which the logics of biopower and plasticity rely. It is another sort of departure. The temporal disjunction of the present supposes not only the internal plasticity or transformability of life (and therefore of biopower inasmuch as it makes life its object), but also the absolute exclusion of everything that does not pertain to this so-called "life": life's others, the inert, the inorganic, the machinic, the monstrous, death and the undead, etc. In attempting to normalize life, biopolitics must define life, performatively: it defines and circumscribes life as such, "life itself," which supposes the exclusion of all its others. The notion of "anachrony," here, is no longer reducible to a temporal figure (at least in the diachronic or synchronic sense); it also accounts for the absolutely unimaginable or unpredictable, the otherness of life before and beyond the living present. This archi-anachrony can no longer be thought as a modification of presence. From the perspective of an ontological discourse on life and power, this radical otherness may only appear as monstrous. As Derrida asks: "Is this other anachrony, this anachrony of the other, not the untimely dimension of the 'present situation,' its unimaginable, unrecognizable, monstrous, unthought face?" (2002a, 81)

I chose my subtitle, "Biopolitics in the face of the event," in order to emphasize a paradox: the event always takes "the formless form of a monstrosity" (Derrida 1990, 80)- -but as such, we can never turn to this "face," because the monstrous as such remains faceless and inconceivable. The monstrous other watches us, but there is no 
turning point from which one can address it, face to face. Monstrosity, just like the event, supposes radical asymmetry and unpower: ${ }^{8}$

All of history has shown that each time an event has been produced. .. it took the form of the unacceptable, or even the intolerable, of the incomprehensible, that is, of a certain monstrosity. (Derrida 1995, 387)

The figure of the monster, the monstrosity of the monstrous brings out a series of problems that complicate the narrative of biopolitics, starting with its Foucauldian elaboration. I think we can all agree on the fact that Foucault had a lot of affection for monsters, an affection that infuses his 1974-1975 lectures Abnormal (2003a). In those lectures, the motif of monstrosity turns out to be deceptively expansive. On the one hand, Foucault strives to distinguish what he calls "the monster" from other specific figures: the "individual to be corrected," the "child masturbator," and finally the "abnormal." However, as is often the case with Foucault's taxonomic classifications and historiographical periodizations, ruptures and discontinuities are easily turned inside out into sutures and continuities. If Foucault succeeds in isolating a determinate figure of "the monster," which he locates roughly in the seventeenth and eighteenth century, it is only through the admission that a certain monstrosity tends to contaminate all other subsequent figures, through effects of haunting, marking, banalization and universalization, appropriation and absorption, affiliation, communication, and, of course, genealogy (2003a, 55-75). Foucault has to admit that there is something of the monstrous that circulates between all these figures, and which continues to "haunt" the abnormal $(56 ; 101)$. "The monster," assumed to be the first of all these figures, becomes the mother of all monsters. It already figures subsequent figures. It engenders monsters without natural birthing. ${ }^{9}$ One of the

\footnotetext{
${ }^{8}$ See also Derrida 2005a, xxiii and xxxiii-xxxiv. On Derrida's event-monsters, see Royle 2003 (103$118)$.

${ }^{9}$ On monstrous births, see Marder 2018.
} 
reasons for such proliferative contagion is that the monstrous problematizes categories such as the norm and the law, and thus navigates between the different economies of power that Foucault is trying to describe in the same lectures. The monster's radical abnormality is also what makes it a powerful example - to the point where the absolute singularity of monstrosity can be turned around into a universal index.

The monster is an exception - an absolute alterity exceeding and violating all preexisting norms, rules, jurisdiction or jurisprudence:

The notion of the monster is essentially a legal notion, in a broad sense, of course, since what defines the monster is the fact that its existence and form is not only a violation of the laws of society but also a violation of the laws of nature. Its very existence is a breach of the law at both levels. The field in which the monster appears can thus be called a "juridico-biological" domain. ... The monster is the limit, both the point at which law is overturned and the exception that is found only in extreme cases. The monster combines the impossible and the forbidden. (2003a, 55-56)

Here, Foucault uses the lexicon of violation: he describes the monster as a transgression, a violent irruption violating both the laws of nature and the laws of society. This double dimension already makes the monster a biopolitical object avant la lettre, so to speak - at this stage Foucault does not speak of "biopolitics"; he describes the monster as pertaining to the "juridico-biological" domain. Double outlawness, then: double breach. However, the (double) monstrous violation cannot be simply envisaged as an exercise of violence; it is not exactly an act of power, either, or against power, because here violation is bound to the very existence of the monster. This violence is another kind of resistance. The essence of the monster is to be a limit, an accident, an essential accident, that is, an accident that cannot be simply reappropriated as pertaining to an essence. ${ }^{10}$ In its singularity, the monster should be irreproducible; it should be understood as its own monstration or demonstration: self-

\footnotetext{
10 The question of essentiality-accidentality is also central to Derrida's discussion of Malabou (2005a, xlxlvii).
} 
manifestation as monstrous exception. The monster should emerge as a pure expression of life "as such," so to say, but a life beyond life, one which exceeds and violates legitimate or "normal" understandings of life. The monster exceeds biopolitical normativity. Because it is exception "itself," the monster should appear beyond all models or patterns. It should instantiate, in its irruption, its own rule, its own model. The apparent paradox is that the monster is the absolute other, but it should function as pure tautology, absolute singularity, a self-contained life-form:

Paradoxically, the monster is a principle of intelligibility in spite of its limit position as both the impossible and the forbidden. And yet this principle of intelligibility is strictly tautological, since the characteristic feature of the monster is to express itself as, precisely, monstrous, to be the explanation of every little deviation that may derive from it, but to be unintelligible itself. Thus, it is this tautological intelligibility, this principle of explanation that refers only to itself that lies at the heart of analyses of abnormality. (2003a, 56-57)

In this sense, the monster would be a pure ipseity, a self-contained exception, an absolute sovereign exceeding traditional representations of sovereignty. Because it is exception "itself," the monster should rule over itself as its own principle of intelligibility. In the terms chosen by Agamben in his interpretation of Benjamin's "divine violence," the monster could be described as a "real state of exception," a "state of actual exception" exceeding the "state of virtual exception" of the sovereign (1998, 54-55; 65). In this perspective, the monster would be exception beyond exception, singular life, unqualified, pure "form-of-life" (188). In this way, Agamben strives to think of a life before and beyond the capture of norms and laws - "life, anomie, anarchic potential ... now appear[ing] in its free and intact form” (2015, 273). ${ }^{11}$

\footnotetext{
${ }^{11}$ Let me say in passing that Agamben's notion of form-of-life is in fact resolutely anthropocentric: "What does this expression mean? It defines a life - human life - in which singular modes, acts, and processes of living are never simply facts but always and above all possibilities of life, always and above all potential"
} 
Nevertheless, the problem is not all that simple. How can one think the "appearing" of an exception? And of the monster? There are at least two ways of thinking the monstrous exception: on the one hand, the monster, because it instantiates a tautological singularity, should be absolutely unreadable and undecipherable, radically other and otherworldly; which also means that, on the other hand, it should break all rules in order to deliver its own rules, the rules we may then use in order to read the monster, to understand it - be it in order to mock it, expel it, cure it, take care of it, or look at it with pity, maybe tenderness... But - here lies the problem - as soon as it is read and demonstrated, as soon as it is understood and classified, the monster is demonsterized: it becomes appropriated and domesticated. It is not a monster anymore, or it is just one monster among others, which one may class according to a taxonomy or typology of monstrous lives - that is, a teratology. In this process, the monster loses its monstrous potency, its subversive force, and is converted into an item among others in order to be managed according to biopolitical normativity and powerknowledge dispositives. By definition, teratology is an impossible science. ${ }^{12}$ This difficulty prompts Derrida to distinguish between normal monsters and monstrous monstrosities:

I shall distinguish between normal monstrosities and monstrous monstrosities which never present themselves as such. A monstrosity never presents itself; or else, if you prefer, it only presents itself, that is, lets itself be recognized, by allowing itself to be reduced to what is recognizable; that is, to a normality, a legitimacy which it is not, hence by not letting itself be recognized as what it is - a monstrosity. A monstrosity can only be "mis-known" [méconnue], that is, unrecognized and misunderstood. It can only be recognized afterwards, when it has become normal or the norm... .

(2015, 207). So, interpreting it in terms of monstrosity as I am doing here might actually constitute a charitable reading. Ethical implications of the monstrous will be brought out in the conclusion of this essay.

${ }^{12}$ Of course, Saussure considers effects of writing as "teratological cases" that should be put in a "special compartment" of linguistics (quoted in Derrida 1997, 42). 
Monsters cannot be announced. One cannot say: "Here are our monsters," without immediately turning the monsters into pets. (1990, 79-80)

The monster is interesting because it is a limit-concept, and Foucault explicitly conceptualized it as such. It is a parasitic or (self-)deconstructive figure, thus allowing to nuance and complicate the biopolitical analytics - and this in view of an opening towards future thinking of resistance. But please let me clarify my intent: I do not mean this as a frontal critique of Foucault's conceptual framework, but rather as a critique of a certain reification and calcification of the conceptual tools which Foucault provided us with. In the last decades, this reification has occurred in certain strands of disciplines such as political science or international studies, which testifies to the problematic use of Foucault as a mere toolkit provider, another bricolage supplier. Do not get me wrong: Foucault himself encouraged bricolage, and this attitude may always be helpful; it has indeed provided powerful critical tools in such or such contextual situations. The biopolitical framework would be such a tool. Nevertheless, the risk in such theoretical practice is to lose the subversive character of Foucault's analytical tools by using them as readymade theoretical models, easily transferable and applicable from one situation to another, in such or such "present," without accounting for the transgressive and self-transgressive force of their underlying conceptuality. In order to avoid reifying Foucault's concepts, I believe we should not only play with those concepts but also return to texts in order to activate the unthought virtualities and subversive potentialities of lesser-known notions.

The monster is such a notion, powerfully deconstructive or self-deconstructive. For instance, the figure of the monster complicates the distinction between sovereign exclusion on the one hand, and biopolitical normativity on the other. Indeed, the monster is said to be exceptional, it is exception itself, but it also testifies to a certain democratization and universalization of the abnormal. In this sense, it testifies to a certain porosity between the normal and the abnormal, and of the irreducible 
possibility of normalizing the exceptional through power-knowledge dispositives. The monster is both exception and model. As such, it already seems to materialize a point of translation and intersection between the sovereign and biopolitical normativity. I quote Foucault:

the monster is, so to speak, the spontaneous, brutal, but consequently natural form of the unnatural. It is the magnifying model, the form of every possible little irregularity exhibited by the games of nature. In this sense we can say that the monster is the major model of every little deviation. It is the principle of intelligibility of all the forms that circulate as the small change of abnormality. (2003a, 56)

Most importantly, the monster is at the very limit between, on the one hand, the power of sovereign law, relying on death and on the symbolics of blood, and, on the other hand, the normative regulation of biopower (instantiated, for example, in what Foucault calls the analytics of sex). Here again, the monster is conceived as an exception, but one internal to the normative logic of biopower:

How can power exercise its highest prerogatives by putting people to death, when its main role is to ensure, sustain, and multiply life, to put this life in order? For such a power, execution is at the same time a limit, a scandal, and a contradiction. Hence capital punishment could not be maintained except by invoking less the enormity of the crime itself than the monstrosity of the criminal, his incorrigibility, and the safeguard of society. One has the right to kill those who represent a kind of biological danger to others.

One might say that the ancient right to take life or let live has been replaced by a power to foster life or disallow it to the point of death. (Foucault 1978, 138; my emphasis; translation modified)

Monstrosity is what comes to disturb biopolitical rationality because it signifies an excess and a threat to the body proper. The monster monstrates a life beyond life, another life that betrays the improperness and impurity of life "as such." This is why monstrosity is the index of all racisms (2003b, 254-263). Foucault thus signals that monstrosity remains a limit within biopolitics, a figure through which the categories of sovereign power and biopower contaminate each other. It is a point where their limits tremble. This monstrous intercontamination also complicates the distinctions between 
notions such as killing, taking life, letting die, letting live, making live, etc. - while also challenging ulterior divisions such as Balibar's positive/negative biopolitics (2002), or Esposito's distinction between "affirmative" and "negative" immunizations (2008), or notions such as "thanatopolitics" (Agamben 1998, 122-123), or "necropolitics" (Mbembe 2003). Through the figure of the monster, biopolitics has always been a necro- or thanatopolitics: there have always been designated "monsters" that one allows himself or herself to kill, to make die or to let die, in the name of a perceived "biological danger." There are innumerable examples of this, and not only in political discourses summoning figures such as "monstrosity," "barbarity," "cruelty," "inhumanity," etc. Is it not the very crux of the logic of autoimmunity, everywhere it operates? In this sense, the management of life (biopower) and the putting-to-death (the sovereign gesture par excellence) may be conceived as co-implicated - and the figure of this intersection is precisely the monstrous beyond-within.

I believe that future debates between biopolitics and (bio)deconstruction will benefit from tracking those effects of conceptual intercontamination or overlapping, as they arguably appear in the texts themselves. In several places, Foucault explicitly names such overlappings - using here, once again, the motif of haunting:

While it is true that the analytics of sexuality and the symbolics of blood were grounded at first in two very distinct regimes of power, in actual fact the passage from one to the other did not come about (any more than did these powers themselves) without overlappings, interactions, and echoes. In different ways, the preoccupation with blood and the law has for nearly two centuries haunted the administration of sexuality. $(1978,149)$

A biodeconstructive-biopolitical analytics should strive to take into consideration effects of "haunting" and spectrality. They complicate the schematic reduction of Foucault's analytics into neat historical periodizations. They also signal an intercontamination of the critical categories put forward by Foucault in order to make sense of power and politics in the form of a "historical ontology of ourselves." There is 
a co-haunting between the symbolics of blood and the analytics of sex, and the monster concerns both. In this sense, the monster is absolutely queer, and intersectional.

I now return to Malabou's critique of Foucault. This critique is based on two claims. The first one is, I believe, quite odd, or at least problematic: Malabou claims that Foucault considers what she calls "symbolic life" as a factor of resistance against biopolitics, as opposed to what she calls "material" or "biological life."13 It is an odd claim because Foucault always highlighted the indissociability of the symbolic and the corporeal - and this is exactly what biopolitical governmentality is about: it intertwines the symbolic/normative and the corporeal/biological in and through the power/resistance continuum. The fact that the "internal" limits of this heterogeneous continuum are not clearly thematized or delimited - Where does "power" start/end? Where does "resistance" start/end? - testifies, precisely, to the plasticity of Foucault's objects and analytical tools, and particularly of the biopolitical logic, before biological and/or symbolic reductions. In fact, the whole point of Foucault's "power-knowledge relations" and "microphysics of power" is to challenge the opposition between the material and the symbolic when it comes to power and the "body politic" (1995, 2628). In addition, Foucault emphasizes the immanent and productive character of power-knowledge, that is, of the multiple, heterogeneous, proliferating forces involved in power relations (1978, 92-102). Incidentally, this thinking of radical immanence (which often brings Foucault and Deleuze together) might actually be closer to Malabou's plastic ontology than she appears to acknowledge in her critique. And when Foucault examines the future of life and power, he does not argue, as Malabou

\footnotetext{
${ }^{13}$ Malabou $(2015 ; 2016)$. In order to disentangle the intricate web of notions that make up Malabou's argument, one would have to define, and fully stabilize, the signification of terms such as "life" itself, "symbolic life," "biological" or "material life," and to clearly differentiate what those names designate in Malabou, Foucault, Agamben, and so on. It is an impossible task-made impossible by effects of "symbolic" or "material" (in short, textual) proliferation, parasitism, and contamination threatening "life" definitions at every turn.
} 
claims, for the abandon of biopolitics in the name of "symbolic freedom" (whatever it may mean). For instance, in a 1976 review of Jacques Ruffié's De la biologie à la culture, Foucault warns against hasty separations between the biological and the culturalhistorical. He also expresses hope for a more polymorphic (more "plastic," perhaps?) biopolitics: “one sees very clearly formulated [in Ruffié's text] the questions of a 'biohistory' that would no longer be the unitary and mythological history of the human species across time, and a 'bio-politics' which would not be one of divisions, selfpreservation, and hierarchies but of communication and polymorphism" (2014, 129). ${ }^{14}$

Malabou's second claim stems from the first one: she suggests that resistances against biopower may only come from within the biological, as a process of plastic selftransformability. "There is one life only," but it is plastic. She offers what she calls a "plastic ontology" (Malabou and Vahanian 2008, 5), a plastic materialism. Plasticity supposes an immanentist conception of life and Being - "Being is nothing but its plasticity" (2010,36) - one that is grounded in the notion that there is no transcendence, "nothing outside." 15 But where does this leave the monster? Let me say this right away: there is no room for monsters in Malabou's conception of plasticity. Although it might seem odd from the standpoint of an ontology that puts the metamorphic character of life front and center, this exclusion of monstrosity in

\footnotetext{
${ }^{14}$ The antibiopolitical stance that Malabou attributes to Foucault seems to me closer to Agamben's. As usual with Foucault, his analytics of power avoid laying out any prescriptive claim, although one can find traces of "affirmative" biopolitics in this reading of Ruffié and other texts.

${ }^{15}$ One peculiarity of Malabou's ontological gesture is to try and separate ontology from presence. She claims that "ontological plasticity" is, before presence: "the mutability of presence is older than presence" $(2010,36)$. She strives to identify plasticity with what she calls "the ontological consistency of the undeconstructible" (201 1a, 88). But, what is a consistency without presence? Malabou's gesture (separating ontology from metaphysics of presence) is indubitably a bold move, which sets her apart from Derrida's deconstruction. But presence inevitably reappears at the level of "life itself," or of "Being" in the form of "ontological plasticity." What is the motto "There is one life only," if not the consecration of life's absolute self-presence?
} 
fact conforms perfectly to Malabou's economy of plasticity, which supposes absolute convertibility and exchangeability:

If we accept, as I have tried to show first with Hegel and then with Heidegger, that alterity can be thought without the aid of transcendence, if it is true that there is nothing outside, nothing beyond - outside the economy and outside the exchangeability or mutability of Being - then there is no inconvertibility. Absolute convertibility, the migratory and metamorphic resource of alterity, is the rule. Absolute exchangeability is the structure. (2010, 46-47)

Monsters are extremely rare in Malabou's texts. When they appear, she exorcizes them right away. For instance, in the course of her stunning reading of Heidegger, one finds a rare occurrence of monsters:

This welcome and arrival or passage into the other neither is pure transcendence, nor does it form a transcendental hospitality; it provokes, it should be recalled, migrations and metamorphoses. There is no alterity without change. The other changes me because I change myself in it. There are, as you know, strange resemblances between people who live together without being kin; between lovers, friends, and children. Alterity is transformation - fashioning of and by the other.

Yet the metamorphosis and migration of Dasein, God, the relation to being, beings, etc., announced by Heidegger corresponds neither to the sudden appearance of new monsters nor to what are ordinarily called fantastic creatures. The new metamorphosis and migration results from the way in which all things, from here out, breathe the same air, and live the same novel ontological condition: beingessence, being-beings, and being the difference between the two. In the midst, again, of this gift form mobile, nomad assemblies, groups of resemblances and "resemblants," and clusters of metamorphoses that all have such-and-such an aspect. (2011c, 173)

What Malabou has in mind is thus a form of limitless expansion and democratization of monstrosity, or what she calls "mutantkin." In this way, plasticity is first and foremost a thought of resemblance and kinship. In the book's conclusion she describes it as such: 
Everything that enters presence passes - is migrated, put en route, and in the same move installed in the very form of its passage.

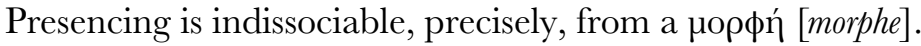

We have changed - this much is certain - and we will keep changing. ... These changes, though, do not again give birth to "fantastic creatures." . . . The fantastic is being like everyone. The fantastic is the new face of the entire world. . . There is no superman, only akin mutants. Mutantkin. (2011c, 286-287)

There are two potential ways of understanding monstrosity in relation to Malabou's immanentist thinking of plasticity: in a first sense, plastic ontology suggests that material life is itself defined as perpetually transforming and changing (itself). In this perspective, there are no monsters, no "real" monsters, only infinite mutations and metamorphoses in the ontological milieu of life. In sum, what we would have, here, is pure evolution - one which may be conceived as linear or explosive, continuous or accidental - but one which always returns to life "itself" (one life only) in the Hegelian sense of dialectics. No monsters, then. Life faces itself wherever it turns. Plasticity is conceived as "a trajectory within the self," "a journey within oneself," "a kind of transformation which would sublate the difference between the self and itself, which would create, produce a new self as a result of the opposition between two forms at work in the self" $(2008,5) .{ }^{16}$ Or, in a second sense, one could say that plastic life is itself the monster: there is one life only, and there is only one monster. But, if life is purely monstrous, if life is the monster "itself," then there are no monsters anymore. The monstrous other is always-already digested by plastic ontology, that is, by its reliance on the authority of selfness, of Being-as-self-presence. In this sense, biopolitics, just like the biological, just like life itself, faces itself wherever it turns and becomes

\footnotetext{
${ }^{16}$ While she is critical of the biopolitical Foucault, Malabou has kinder words for the later Foucault of The Hermeneutics of the Subject, and in particular for his concept of "transsubjectivation": "This transsubjectivation doesn't mean that you become different from what you used to be, nor that you are able to absorb the other's difference, but that you open a space within yourself between two forms of yourself. That you oppose two forms of yourself within yourself." Clearly, Malabou is interested in a dialectical, Hegelian Foucault: "Plasticity might be the name of this transsubjectivation" $(2008,5)$.
} 
potentially limitless: "one life only," and "nothing outside" — but is this not the very rationale of capitalist biopolitics? This is the crux of Alexander Galloway's critique of Malabou, wherein some monster seems to show its face:

one wonders if Malabou's commerce of being is not too intimately related to the mode of production. In other words, is a theory of plasticity necessarily also a theory of today's economy? Malabou's plasticity is a voracious monster that can gobble up any and all foes into itself. Of course, one says the same of Hegel's dialectic, but one also says the same of neoliberal capitalism. (2010, 15; my emphasis)

Galloway is very harsh here (his essay is explicitly framed as polemical) - and it is not certain that his passing mention of the monstrous is as charitable, or hospitable, as I would like it to be- but his critique remains nonetheless powerful in its structure. This is not to say that Malabou is a neoliberal apologist or ideologist, of course. And here is not the place to deliberate on what neoliberal capitalism supposedly "is," on the limits of that "thing" which, just like "biopolitics," would require an infinite work of historical-textual interpretation. In several places, Malabou herself strives to differentiate between her concept of plasticity and capitalist flexibility (2011b; 2011c). However, it is worth noting the theoretical difficulties faced by a plastic materialism relying on an ontology of presence and immanence. In and through the ontological gesture ("one life only") - that is, the onto-logic of life as economy of self-productionreproduction, to which Galloway too succumbs in his above argument - there is no room left for the aneconomic difference of absolute heterology, that is, for the monstrous event exceeding economy and ontology: life's other, nonlife, death, the absolutely untranslatable, unsubstitutable, and irreproducible singularity - or what Malabou calls, in order to discard it immediately, the inconvertible.

Here again, the question might be formalized in temporal terms. An ontological approach to life - life as such or life itself - can only result in "presentism," that is, in a reduction of being and biological life to present forms, present categories of intellection 
or experience. ${ }^{17}$ How can something like "bio-logy" (that is, always, the present state of biological discourses, of any discourse that takes "life" as its object, or makes life its object) escape the traps of what Derrida called logocentrism, and the contaminating effects of the triple folding described above in my reading of Foucault? Theoretical presentism may always testify to a collusion (or at least an intercontamination) with current power-knowledge dispositives, to speak like Foucault; or, in Marxian terms, with presently dominant class interests, modes of production, in short, material or economic forces and correlated ideological or epistemic structures of cognition. Malabou would certainly admit, to an extent, the necessity of this complicity (201 lb). Indeed, the property of mutability, which is one of the chief traits of plastic ontology, may always be turned around into conformist flexibility: certainly, the plasticontological gesture supposes an essential transformability; but where does this gesture find resources for arming itself against conformability - where, then, beside in life itself, which is precisely the issue at stake? "Life itself," that is to say: present forms or categories, theoretical and practical - in other words, performative - that inform one's understanding and government of life, of life by itself, in and through the hermeneutic circle of autopoiesis. Hence biopower (be it from the perspective of power or resistance, both dimensions being co-implicated in Foucault's analytics) becomes reducible to its present capacities or potentialities, informed by its own power of selfperformance. In this performance, the distinction between "symbolic life" and "biological life" is no longer relevant. Certainly, self-performance and selflegitimation are inseparable from the logic of power-but where does this leave the

\footnotetext{
${ }^{17}$ An illustration of this difficulty appears in Malabou's most recent book, Morphing Intelligence (2019), which starts with a self-critique: while she used to consider "artificial life" and "artificial intelligence" as non-plastic (and thus as instances of nonlife), she now welcomes them in the framework of her plastic ontology of life: "There is one life only" (144). Certainly, one could argue that Malabou's self-critique testifies to the plasticity of plasticity. But, is it not rather the sign of a more structural difficulty, linked to Malabou's persistent ontological framing of life and of what is to be understood under that old name, "life"? Monstrosity will forever be the index of this difficulty. All monsters start by being excluded; but here ontological inclusion is equally problematic.
} 
question of resistance? Here, the issue of ontology (especially that of a political ontology of life, of onto-biopolitics) intersects with that of presentism - and this constitutes, precisely, a materialist intersection, or one that can always be read according to a materialist interpretation. As Andrew Cole puts it: "Presentism happens when any theory conforms its critical insights to the very theory late capitalism offers of itself” (2015, 816).

Let me make this very clear: what I describe here as "materialist interpretation" is anything but an escape from "life," "materiality," or "reality" - for instance in the form of idealism, linguisticism, or symbolism. ${ }^{18}$ On the contrary, it concerns the very materiality of text and reading, the materiality of a singular life-event without presence, resisting ontological reductions of life, form, and matter. The question of plasticity, transformability, or conformability, of its correlation to present forms of production, may be discussed and interpreted indefinitely; but the event of "an interpretation that transforms the very thing it interprets" (Derrida 1994, 63) may occur only through a forceful opening to the impossible, beyond life's present "capacities" or "possibilities" of self-transformation, before and beyond the presence of the present and the proximity of an ontology. In "Typewriter Ribbon," Derrida describes this "materiality without matter" as a "force of resistance":

The materiality in question. . . is not a thing, it is not something sensible or intelligible; it is not even the matter of a body. As it is not something, as it is nothing and yet it works, cela oeuvre, this nothing therefore operates, it forces, but as a force of resistance. It resists both

\footnotetext{
${ }^{18}$ In recent essays $(2014 ; 2015)$, Malabou attributes to Derrida the outlandish claim that "biological life" is essentially programmatic, and that "the promise" exceeds "biology" so as to occur as a "symbolic" promise of "meaning" external to biology. One quick look through Vitale's Biodeconstruction is enough to dissipate this argument. First, what is "biological life"? What are the limits of that "thing"? Second, Derrida never separated the program from the promise; both must be thought together, in indissociable heterogeneity. This irreducible heterogeneity is the signature of the monstrous event. Third, the promise is certainly not "symbolic," and cannot be reduced to a promise of meaning. It is a non-symbolizable excess beyond meaning, within meaning. As usual, Malabou seems to refuse what Derrida thinks in the formless form of the "beyond-within," transcendence in immanence: the internal alterity or anachrony that is the mark of monstrosity, life-death, sur-vie, hypervitality, or the im-possible. All these notions - and the rest of this essay - tie in with Biodeconstruction's last chapter on the arche-performative (Vitale 2018, 185-199).
} 
beautiful form and matter as substantial and organic totality. . . I

would say that it is a materiality without matter. (Derrida 2002b, 151)

This force of resistance cannot be ignored - but can it be said that it simply belongs to "life" (even a "plastic" life), to the "proper" or "selfness" of life, power, or biopower? And is it certain that we can or should conceptualize it in the modality of "belonging" or "property" - and, even, of conceptuality?

Yet, cela oeuvre. And monstrosity exists - though it cannot and should not take the form of a being-present, of being collected in the discourse of presence. There "is" no monster - but ily a, es gibt, du monstre. What remains to be thought is this gift, the originary affirmation of a monstrous life without being, preceding and exceeding being itself as well as ontological reductions or recollections of life:

It is not a principle, a princedom, a sovereignty. It comes then from a beyond the beyond, and thus from beyond the economy of the possible. It is attached to a life, certainly, but to a life other than that of the economy of the possible, an im-possible life no doubt, a survival, not symbolizable, but the only one that is worthy of being lived, without alibi, once and for all, the only one from which to depart (notice I say from which to depart) for a possible thinking of life. (Derrida 2002b, 276)

One must think monstrosity before and beyond its reductions into monstrous "beings." One must think of an originary monstrosity, nondelimitable, nonphenomenologizable, and non-ontologizable. In its irreproducibility and inconvertibility, monstrosity materializes an irreducible resistance before the Self, before the self-performance of an ipseity, any ipseity, be it that of "life itself" or "Being itself"; but it also interrogates current appeals to "ontology," be it in the form of "plastic ontology," "new realisms," or "new materialisms." In ontological or presentist form, so-called "realism" can only confirm the economy of presence in its performative power of appropriation and normalization (Cole 2015) - thus neutralizing the aneconomic event and confirming a certain state of the biopolitological order. We lose monsters as soon as they are singled out in the present, 
onto-phenomenologized as beings, being-present - usually in order to become manageable and readily disposable in the form of biopolitical categories. Monsters are ignored and domesticated as soon as they are "presentified," located and designated, classified and typologized, violently tamed and reduced into pets through the powerful gesture of a performative. Certainly, this gesture might always be justified in itself, in the presence of the present - it is, after all, before and beyond the Foucauldian motif of biopower, the pivotal gesture of any politics taking life as its object, justifying its own violence in the name of "biological danger," for instance. Such practices will always be somewhat justifiable, and perhaps necessary. But those justifications remain conditional and contextual, and therefore deconstructible, and incommensurable to unconditional injunctions such as hospitality, forgiveness, or justice. These injunctions address themselves to the monstrous irruption of the other, and as such they are mandated by this irruptive force - the force of the event - which, like the monstrous, precedes and exceeds onto-biopolitical reductions of life. The monstrous monstrosity resists power-knowledge and any form of economic appropriation. It should remain inappropriable; it is the condition for ethical responsibility towards the other: "The nonethical opening to ethics. A violent opening” (Derrida 1997, 140). This is where resistance against power-resistance tout court - starts: in the affirmation without presence of the monstrous event before and beyond its reduction into normative conventions and ontological categories. Before onto-biopolitics, before "mutantkin," there is, perhaps, justice for the monster:

But does one only have duties toward man and the other man as human? And, above all, what are we to reply to all those who do not recognize their fellow in certain humans? This question is not an abstract one, as you know. The worst, the cruelest, the most human violence has been unleashed against living beings, beasts or humans, and humans in particular, who precisely were not accorded the dignity of being fellows (and this is not only a question of profound racism, of social class, etc., but sometimes of the singular individual as such). A principle of ethics or more radically of justice, in the most difficult sense, which I have attempted to oppose to right, to distinguish from right, is perhaps the obligation that engages my responsibility with respect to the most dissimilar [le plus dissemblable, 
the least "fellow"-like], the entirely other, precisely, the monstrously other [my emphasis], the unrecognizable other. The "unrecognizable" [méconnaissable], I shall say in a somewhat elliptical way, is the beginning of ethics, of the Law, and not of the human. So long as there is recognizability and fellow, ethics is dormant. It is sleeping a dogmatic slumber. So long as it remains human, among men, ethics remains dogmatic, narcissistic, and not yet thinking. Not even thinking the human that it talks so much about.

The "unrecognizable" is the awakening. It is what awakens, the very experience of being awake. (Derrida 2009, 108)

The awakening is thus a gift from the inconvertible, "monstrously other." And this is why there cannot, there should not be any ontology of the monster. No name for it. Life-beyond-life that keeps us awake, alive, like as many births. But in the gift of this affirmation, life can no longer be opposed to death. How can one think this gift before or beyond ontological reconstructions of life-death and monstrosity, before and beyond all given forms or names? What does it mean to affirm life without being? And is it still a matter of meaning?

In the monstrous, life resists meaning. It resists naming. It gives itself in this force of resistance. I started by saying that Vitale's book is a major book on, and of, resistance. This resistance starts with that very first of awakenings: resisting a name. Does anyone, does any "life" ever resist anything but names, given names, and the patronymic power they carry - thus resisting against all sorts of filiation, genealogy, or program? Resistance starts with name-resistance: resisting one's name, resisting one's present, resisting oneself in the name of the monstrous, unnameable other. Signature apposed, and immediately resisted. Here is the gift, the auto-hetero-biothanatographical gift of Biodeconstruction: Francesco resisting his "own” signature, his "own" proper name, the proper of a name he did not choose. Vitaledeconstruction. 


\section{REFERENCES}

Agamben, Giorgio. 1998. Homo Sacer: Sovereign Power and Bare Life, trans. Daniel HellerRoazen. Stanford: Stanford University Press.

- 2016. The Use of Bodies, trans. Adam Kotsko. Stanford: Stanford University Press.

Balibar, Étienne. 2002. Politics and the Other Scene. London and New York: Verso.

Cole, Andrew. 2015. The Function of Theory at the Present Time. PMLA 130, no. 3: 809818.

Derrida, Jacques. 1990. Some Statements and Truisms about Neologisms, Newisms, Postisms, Parasitisms, and Other Small Seismisms, trans. Anne Tomiche. In The States of Theory, ed. David Carroll, 63-94. New York: Columbia University Press.

- 1994. Specters of Marx: The State of the Debt, the Work of Mourning and the New International, trans. Peggy Kamuf. New York and London: Routledge.

- 1995. Points... Interviews, 1974-1994, ed. Elizabeth Weber, trans. Peggy Kamuf. Stanford: Stanford University Press.

- 1997. Of Grammatology, trans. Gayatri C. Spivak. Corrected ed. Baltimore and London: Johns Hopkins University Press.

- 2002a. Negotiations: Interventions and Interviews, 1971-2001, ed. and trans. Elizabeth Rottenberg. Stanford: Stanford University Press.

- 2002b. Without Alibi, ed. and trans. Peggy Kamuf. Stanford: Stanford University Press.

- 2005a. Preface. In Catherine Malabou, The Future of Hegel: Plasticity, Temporality and Dialectic, trans. Lisabeth During. London and New York: Routledge.

- 2005b. Rogues: Two Essays on Reason, trans. Pascale-Anne Brault and Michael Naas. Stanford: Stanford University Press.

- 2009. The Beast and the Sovereign. Vol. 1, trans. Geoffrey Bennington. Chicago: University of Chicago Press.

Esposito, Roberto. 2008. Bios: Biopolitics and Philosophy, trans. Timothy Campbell. Minneapolis: University of Minnesota Press.

Foucault, Michel. 1978. The History of Sexuality. Vol. 1, An Introduction, trans. Robert Hurley. New York: Pantheon Books.

- 1995. Discipline and Punish: The Birth of the Prison, trans. Alan Sheridan. $2^{\text {nd }}$ ed. New York: Vintage Books.

- 2003a. Abnormal: Lectures at the Collège de France 1974-1975, trans. Graham Burchell. London and New York: Verso.

—. 2003b. "Society Must Be Defended": Lectures at the Collège de France 1975-1976, trans. David Macey. New York: Picador.

- 2007. The Politics of Truth, trans. Lysa Hochroth and Catherine Porter. Los Angeles: Semiotext(e). 
- 2014. Bio-History and Bio-Politics, trans. Richard A. Lynch. Foucault Studies 18: 128130.

Galloway, Alexander. 2010. French Theory Today: An Introduction to Possible Futures. New York: Erudio.

Hamacher, Werner. 1999. Lingua Amissa: The Messianism of Commodity-Language and Derrida's Specters of Marx. In Ghostly Demarcations, ed. Michael Sprinker. London and New York: Verso.

Malabou, Catherine. 2010. Plasticity at the Dusk of Writing: Dialectics, Destruction, Deconstruction, trans. Carolyn Shread. New York: Columbia University Press.

- 2011 a. Changing Difference: The Feminine and the Question of Philosophy, trans. Carolyn Shread. Cambridge: Polity.

- 2011b. Que faire de notre cerveau? 2 $2^{\text {nd }}$ ed. Paris: Bayard.

—. 2011c. The Heidegger Change: On the Fantastic in Philosophy, trans. Peter Skafish. New York: SUNY Press.

- 2014. Déconstruire la résistance philosophique à la biologie. Quadranti 2, no. 2: 3346.

- 2015. Will Sovereignty Ever Be Deconstructed? In Plastic Materialities: Politics, Legality, and Metamorphosis in the Work of Catherine Malabou, eds. Brenna Bhandar and Jonathan Goldberg-Hiller, 35-46. Durham and London: Duke University Press.

- 2016. One Life Only: Biological Resistance, Political Resistance, trans. Carolyn Shread. Critical Inquiry 42: 429-438.

—. 2019. Morphing Intelligence: From IQ Measurement to Artificial Brains, trans. Carolyn Shread. New York: Columbia University Press.

Malabou, Catherine; and Noëlle Vahanian. 2008. A Conversation with Catherine Malabou. Fournal for Cultural and Religious Theory 9, no. 1: 1-13.

Marder, Elissa. 2018. Derrida's Matrix: The Births of Deconstruction. Oxford Literary Review 40, no. 1: 1-19.

Mbembe, Achille. 2003. Necropolitics, trans. Libby Meintjes. Public Culture 15, no. 1: 11-40.

Mercier, Thomas Clément. 2018. We Have Tasted the Powers of the Age to Come: Thinking the Force of the Event- from Dynamis to Puissance. Oxford Literary Review 40, no. 1: $76-94$.

- 2019. Diferencia sexual, diferencia ideológica: lecturas a contratiempo (Derrida lector de Marx y Althusser en la década de 1970 y más allá), trans. Carolina Collazo and Ramiro Parodi. Demarcaciones 7.

Royle, Nicholas. 2003. Facques Derrida. London and New York: Routledge.

Vitale, Francesco. 2018. Biodeconstruction: Facques Derrida and the Life Sciences, trans. Mauro Senatore. New York: SUNY Press. 